\title{
The Role of Supply Constraints in Multiplier Analysis ${ }^{1}$
}

\author{
M. ALEJANDRO CARDENETE \\ Department of Economics \\ Universidad Pablo de Olavide \\ Ctra. Utrera, km.1 \\ 41013 - Sevilla, SPAIN \\ macardenete@upo.es
}

\author{
FERRAN SANCHO \\ Department of Economics \\ Universitat Autònoma de Barcelona \\ 08193 - Bellaterra, Catalonia, SPAIN \\ ferran.sancho@uab.cat
}

Preliminary First draft: February 2010

\footnotetext{
${ }^{1}$ Support from research grants MICINN-ECO2009-11857 and SGR2009-578 is gratefully acknowledged. Corresponding author: M. A. Cardenete, email: macardenete@upo.es
} 


\begin{abstract}
Multiplier analysis based upon the information contained in Leontief's inverse is undoubtedly part of the core of the input-output methodology and numerous applications an extensions have been developed that exploit its informational content. Nonetheless there are some implicit theoretical assumptions whose implications have perhaps not been fully assessed. This is the case of the 'excess capacity' assumption. Because of this assumption resources are available as needed to adjust production to new equilibrium states. In real world applications, however, new resources are scarce and costly. Supply constraints kick in and hence resource allocation needs to take them into account to really assess the effect of government policies. Using a closed general equilibrium model that incorporates supply constraints, we perform some simple numerical exercises and proceed to derive a 'constrained' multiplier matrix that can be compared with the standard 'unrestricted' multiplier matrix. Results show that the effectiveness of expenditure policies hinges critically on whether or not supply constraints are considered.
\end{abstract}

Keywords: Key sectors, Economic linkages, Policy evaluation, Economy-wide modeling, General equilibrium.

JEL: C63, C68, D58 


\section{INTRODUCTION}

There is some widely accepted wisdom concerning the effectiveness of government expenditure policies. Since economic sectors differ in terms of their 'push' and 'pull' effects, the sector where injections are applied becomes a relevant issue for policy makers who wish to maximize the impact of government policies (Devarajan et al, 1993). The literature has therefore provided the concept of 'key sectors' as a guiding principle to authorities in regard to policy design. The 'key sector' concept and

measurement, however, depends on a series of assumptions that have not been questioned. In practical terms, a sector is deemed to be 'key' when an exogenous expenditure inflow falling on it is 'multiplied' over and above some reference average levels. The key word here is 'multiplied' and this explains why multiplier matrices play such a significant role in the 'key sector' literature.

A multiplier matrix is a numerical description of how an exogenous inflow into one sector ends up affecting the rest of sectors once the set of structural interconnections is fully taken into account. The better known multiplier matrix is the classic Leontief inverse built from the matrix of direct technical coefficients in the interindustry model (Leontief, 1941). Beyond direct interdependencies, Leontief's inverse is able to pick up in a simple and systematic way indirect ones 'down the line' in the production process. Refinements of the multiplier matrix have incorporated additional layers of interdependencies, especially related to the feedback between output, factors' income and consumption demand. These are the so called induced effects. The fact that the standard interindustry model neglected the induced effects linked to final demand was correctly pointed out by Diamond $(1974,1976)$ in his work dealing with development issues. When final demand is left unexplained, 'key sectors' measurements are bound to be downward biased. Diamond tackles this issue incorporating into the input-output 
model a demand subsystem. Another formulation, perhaps a bit more elegant and compact in formal terms, is the SAM (Social Accounting Matrix). A SAM captures the whole circular flow of income in a unified but disaggregated configuration and allows selecting accounts endogeneity in quite a simple way (Pyatt \& Round, 1979, and Pyatt, 1985). In fact, Diamond's approach is a particular case of the SAM approach for a particular class of endogenous accounts.

The computation of multiplier matrices, however, does not question a pivotal assumption in the model, namely, that there is an excess supply of factors. This means that resources can be commanded as needed and prices are unaffected by resource reallocation. In other words, there are no binding constraints. But economics is the science of scarce resources and constraints do act in limiting what can be done. Guerra \& Sancho (2009), for instance, examine how the government budget constraint affects the value of multipliers. With a fixed expenditure level, any reshuffling in the basket of goods purchased by the government gives rise to both income and substitution effects that work in opposite directions. Thus, and against the usual multiplier intuition, multiplier values can in fact be seen to be negative. In more general terms, when resource constraints are at work, extra resources for producing more of a good can only be found if they are shifted from elsewhere. If factors of production are not available beyond a set amount, this entails an economy-wide general reallocation where, once again, output and price effects will be at play. Under this wider, more comprehensive scenario a suitable tool of analysis is that of computable general equilibrium models (CGE). The advantage of a CGE is that integrates price and quantity adjustments of demand and supply following the tenets of well known and well understood economic theory. Using a CGE model of the Spanish economy we estimate a matrix of multipliers which is in fact a numerical approximation for the Jacobian of the reduced model form. 
We then compare this 'constrained' multiplier matrix with the standard 'unrestricted' Leontief inverse.

The paper is organized as follows. Section 2 succinctly describes the basic CGE model and database. Section 3 exposes the underlying methodology for the computation of multiplier matrices. In Section 4 we recap and discuss the empirical results. Section 5 concludes and summarizes. An Appendix includes the detailed numerical results.

\section{THE MODEL AND DATABASE}

The CGE model we use follows the basic principles of the Walrasian equilibrium concept. Kehoe et al. (2005) is very good up-to-date review of this kind of models. Our model includes 26 sectors and is enlarged by including both public and foreign activities. Tax rates are fixed at benchmark values whereas the expenditure activities of the government are taken as exogenous as the result of a policy decision. The activity level of the foreign sector is assumed to be fixed, in the sense that the total amount of exports is independent of the domestic variables. Imports, on the other hand, are imperfect substitutes of domestic production following an Armington hypothesis and its level is endogenously determined. Thus the foreign sector may incur in a deficit which is endogenously determined.

Relative prices and activity levels of the productive sectors are endogenous variables too. Agents behave rationally as utility and profit maximizers. We consider a representative consumer that formulates demand for current and future consumption maximizing a utility function subject to a disposable income budget constraint. Firms are organized in productive sectors and they strive to maximize profits. Because constant returns-to-scale are assumed, this entails in practice that firms are cost minimizers. Final and intermediate demand for goods and services and supply of goods 
and services by firms is coordinated through the price mechanism. In its simplest expression, an equilibrium for this economy is a pair of vectors of prices (for goods and factors) and activities (for goods and factors) so that demand equals supply in all markets. An exception to this rule is contemplated in the labor market where idle resources can be modeled as a proxy for unemployment. This is performed introducing a feedback between the real wage and the unemployment rate that relates to the power of unions, or any other socioeconomic, factors inducing frictions in the labor market (see Kehoe et al., 1995). This feedback is controlled with an elasticity that allows for two polar representations of the labor market. On the one hand, unemployment can be kept fixed if wages are flexible enough; on the other hand, when wages are rigid enough unemployment fluctuates.

The production technology is given by a nested production function. The domestic output of a sector is obtained by combining, through a Leontief technology, outputs from the rest of sectors and value-added. In turn, this value-added is generated from primary factors (labor and capital) using a Cobb-Douglas aggregator. The overall output of a sector is obtained too from a Cobb-Douglas combination of domestic output and imports, according to the aforementioned Armington hypothesis.

The government raises taxes to obtain public revenue which returns to the private sectors in the form of social transfers and in the form of public demand for goods and services. The government may also incur in a deficit if accrued tax collections are not enough to cover for all public outlays.

Regarding investment and savings, this is a savings driven model. The closure rule is defined in such a way that investment is determined by total savings (private, public and foreign). Public and foreign savings are related to the endogenous deficit (or surplus) of the government and the rest of the world. Private savings are also 
endogenous and are the result of the utility maximization problem of the representative consumer.

The economic data used in the study comes from a Social Accounting Matrix of the Spanish economy for 2000 developed by Cardenete \& Fuentes (2009). The SAM comprises a total of 38 accounts, including the already mentioned 26 productive sectors, two primary factors (labor and capital), a savings/investment account, a government account, a direct tax account (income tax and employees' Social Security contribution), an indirect tax account (VAT, payroll tax, output tax and tariffs), a foreign sector and a representative consumer account.

The values for the technological coefficients, the tax rates and the coefficients of the utility function are calibrated to reproduce the 2000 SAM as an initial or benchmark equilibrium for the economy. In the simulations, the wage rate is taken as numéraire and the rest of prices vary as required to meet equilibrium conditions.

\section{THE MULTIPLIER MATRICES}

We consider an $n(n=1,2,3 \ldots, 26)$ good economy described by a technology of intermediate consumptions $A$-an $n \times n$ matrix with fixed coefficients-and price responsive, variable labor and capital coefficients. The equilibrium outputs in this economy is represented by the $n$ vector $X=\left(X_{1}, X_{2}, \ldots X_{n}\right)$ whereas market clearing prices for goods is given by the $n$ vector $p=\left(p_{1}, p_{2}, \ldots, p_{n}\right)$. The government formulates public demand for these $n$ goods that appears in an $n$ vector $G=\left(G_{1}, G_{2}, \ldots, G_{n}\right)$ and constitutes part of the economy's final demand (along with private consumption, investment and foreign demand). In the standard interindustry model, the matrix $A$ is all that is needed to obtain the direct and indirect effects that yield the multiplier matrix $L$ ( $L$ for Leontief) that provides information on the effects of increasing in one unit the level of 
government spending. If $A$ is a productive matrix (see Nikaido, 1972), then $L$ can be calculated using the matrix series expansion or directly through matrix inversion:

$$
L=I+A+A^{2}+A^{3}+\ldots . .=(I-A)^{-1}
$$

The generic element $\ell_{i j}$ of $L$ is known to have the following differential or 'ratio' meaning:

$$
\ell_{i j}=\frac{\Delta X_{i}}{\Delta G_{j}}
$$

The 'multiplier' concept is clear. When the government increases in one unit its demand for good $j$, equilibrium output in sector $i$ needs to adjust in $\ell_{i j}$ units. In the calculation of matrix $L$, however, and because of the 'excess supply' assumption of the Leontief model, additional resources are always available as needed. We may therefore choose to call this matrix the 'unrestricted' multiplier matrix. In an economy with supply constraints, in contrast, resources are not always available, and this set-up is the proper terrain of a CGE model. If more of good $j$ is demanded, by the government say, a general reallocation in prices and quantities will be required in order to fulfil the extra demand for $j$. The appraisal of the effect of the additional demand can be obtained from a numerical approximation of the Jacobian matrix of the CGE equilibrium equations. Let us denote by $M$ this matrix. Then:

$$
m_{i j}=\frac{\partial X_{i}(p, G, u)}{\partial G_{j}}=\lim _{\Delta G_{j} \rightarrow 0} \frac{\Delta X_{i}}{\Delta G_{j}}
$$

Here $X_{i}(p, G, u)$ symbolizes the dependence of quantities $X$ on endogenous prices $p$, policy decisions $G$ and the labor market situation as indicated by the unemployment rate $u$. The numerical 'multiplier' matrix derivative $M$ is computed comparing the benchmark equilibrium values with the counterfactual equilibrium values that ensue from a 'small' change $\Delta G_{j}$ in public demand for $j$. The CGE model absorbs the 'small' 
change and recomputes the equilibrium for $n$ sequential runs where $j=1,2, \ldots, n$. Thus, the $n$ simulations yield an $n \times n$ matrix of 'constrained' multipliers.

\section{DISCUSSION}

The complete results of the analysis can be found in the Appendix. We calculate three multiplier matrices. The first one corresponds to the 'unrestricted' Leontief inverse $L$ and is shown in Table A1. Aggregate multiplier values are shown as column sums. We also calculate two 'constrained' multiplier matrices which correspond to two different labor market scenarios within the CGE modeling facility. In the first one total primary factors (labor and capital) are kept at the initial levels. Any reshuffling in production, in response to a change in expenditure policies by the government, takes necessarily place under these aggregate resource constraints. Factors are mobile among sectors though. With a fixed level of labor, equilibrium adjustments in the labor market occur via prices. In the CGE model this is controlled by an elasticity between the wage rate and the unemployment rate with a zero value. Table A2 shows the multiplier matrix $M$ in this case with a fixed or rigid amount of total labor. The second labor market scenario relaxes the restriction in the use of labor. Now more labor can be commanded if needed. This characterization of the labor market is relevant from the viewpoint of the Spanish economy where high levels of labor are unused and cannot be employed under normal circumstances. Again, an elasticity with value $\infty$ takes care of this scenario in the CGE, where adjustments take now place in labor quantities for a fixed wage rate. Results for $M$ under this flexible labor market case are presented in Table A3. Because of the large amount of numerical data, we just present a summary of the overall results in this Section. Table 1 shows the aggregate multiplier value for the 26 goods. Table 2 presents the 'own' multiplier value for each good and Table 3 presents the net value 
indicating pull effects as they spread in the rest of sectors. In Table 1 we can see that there is a huge difference in total multiplier effects when supply constraints are taken into account (50.603 from $L$ versus 3,075 and -5.611 from $M$ 'rigid' and $M$ 'flexible', respectively). Notice that the habitual and expected positive multiplier effect no longer holds true. In the 'flexible' scenario, in fact, the total aggregate effect is negative. Even though more labor can in principle be commanded in this 'flexible' scenario, the general reallocation in prices and quantities produces 'crowding out', a familiar possibility extensively discussed in standard macroeconomics (see Barro, 2009) that is replicated here in the CGE microeconomic model. More government expenditure gives rise to a contraction, which is larger in magnitude, in the rest of final demand entries and less labor is employed. The message here is that well-meaning policy decisions undertaken by the government may not necessarily produce the intended results. The stimulus packages put into action to face the current economic recession may therefore give way, in fact, to perverse results. When we look at the data in Tables 2 and 3 we observe that the 'own' multiplier value is least affected by the general reallocation. Their values are smaller, as expected, in the constrained scenarios but not substantially. The main drag that curbs the potential 'unrestricted' multiplier values is found in the reduction in activity levels in the rest of sectors. Sectoral changes in other sectors' output are now negative and individually small but their aggregation may counteract the induced 'own' effect and even reverse its sign, as we have seen in Table 1 above for the 'flexible' scenario. These summary results can be further scrutinized reading the Tables in the Appendix where very specific sectoral detail is provided but we believe the main message is sufficiently clear. Supply constraints seem to matter and it would be advisable to incorporate them when evaluating expenditure policy strategies using multiplier estimates. 
Table 1: Total sum of multipliers.

\begin{tabular}{|l|c|c|c|}
\hline Sectors & L & CGE1 & CGE2 \\
\hline 1. Agriculture, cattle and forestry & 1,939 & $-0,675$ & $-2,524$ \\
\hline 2. Fishing & 2,012 & $-0,111$ & $-0,437$ \\
\hline 3. Coal & 2,075 & $-0,059$ & 0,113 \\
\hline 4. Oil and Gas & 1,016 & 0,982 & 0,967 \\
\hline 5. Rest of extractives & 2,121 & 0,381 & $-0,038$ \\
\hline 6. Refine & 1,694 & 1,114 & 0,852 \\
\hline 7. Electricity & 1,983 & $-0,094$ & $-1,400$ \\
\hline 8. Water & 1,747 & 0,874 & 0,102 \\
\hline 9. Distribution of water & 2,011 & $-0,266$ & $-0,502$ \\
\hline 10. Food & 2,332 & 0,299 & $-0,312$ \\
\hline 11. Manufacturing of textiles and leather & 2,151 & 0,378 & 0,230 \\
\hline 12. Manufacturing of wood & 2,172 & 0,384 & 0,035 \\
\hline 13. Chemicals & 1,994 & 0,553 & 0,296 \\
\hline 14. Mining & 2,223 & 0,023 & $-0,329$ \\
\hline 15. Manufacturing of metal products & 2,009 & 0,446 & 0,059 \\
\hline 16. Machinery & 2,142 & 0,192 & 0,129 \\
\hline 17. Manufacturing of textiles and leather & 1,798 & 0,527 & 0,472 \\
\hline 18. Manufacturing of construction material & 2,000 & 0,853 & 0,760 \\
\hline 19. Transport & 1,917 & 0,502 & 0,687 \\
\hline 20. Other manufactures & 2,161 & 0,244 & 0,127 \\
\hline 21. Construction & 2,287 & $-0,084$ & $-0,016$ \\
\hline 22. Vehicles & 1,982 & $-0,278$ & $-0,353$ \\
\hline 23. Commerce & 1,800 & $-0,857$ & $-1,331$ \\
\hline 24. Transport and Communications & 1,851 & $-0,431$ & $-1,209$ \\
\hline 25. Commercial Services & 1,614 & $-0,643$ & $-0,634$ \\
\hline 26. Non-commercial services & 1,571 & $-1,181$ & $-1,359$ \\
\hline TOTAL & $\mathbf{5 0 , 6 0 3}$ & $\mathbf{3 , 0 7 5}$ & $-5,611$ \\
\hline SourCe: Own elaris & & & \\
\hline
\end{tabular}

Source: Own elaboration.

$\mathrm{L}$ : Leontief inverse

CGE1: CGE with rigidity in labor market

CGE2: CGE with flexibility in labor market 
Table 2: Principal Diagonal.

\begin{tabular}{|l|c|c|c|}
\hline Sectors & L & CGE1 & CGE2 \\
\hline 1. Agriculture, cattle and forestry & 1,107 & 1,080 & 1,051 \\
\hline 2. Fishing & 1,002 & 1,001 & 1,001 \\
\hline 3. Coal & 1,005 & 1,002 & 1,003 \\
\hline 4. Oil and Gas & 1,001 & 1,002 & 1,002 \\
\hline 5. Rest of extractives & 1,008 & 0,993 & 0,990 \\
\hline 6. Refine & 1,088 & 1,084 & 1,079 \\
\hline 7. Electricity & 1,173 & 1,154 & 1,141 \\
\hline 8. Water & 1,000 & 0,999 & 0,997 \\
\hline 9. Distribution of water & 1,002 & 1,001 & 1,000 \\
\hline 10. Food & 1,228 & 1,208 & 1,186 \\
\hline 11. Manufacturing of textiles and leather & 1,246 & 1,240 & 1,238 \\
\hline 12. Manufacturing of wood & 1,324 & 1,294 & 1,288 \\
\hline 13. Chemicals & 1,205 & 1,178 & 1,172 \\
\hline 14. Mining & 1,093 & 0,997 & 0,986 \\
\hline 15. Manufacturing of metal products & 1,101 & 1,058 & 1,050 \\
\hline 16. Machinery & 1,088 & 1,005 & 1,003 \\
\hline 17. Manufacturing of textiles and leather & 1,141 & 0,983 & 0,977 \\
\hline 18. Manufacturing of construction material & 1,298 & 1,240 & 1,236 \\
\hline 19. Transport & 1,144 & 1,126 & 1,128 \\
\hline 20. Other manufactures & 1,102 & 1,038 & 1,034 \\
\hline 21. Construction & 1,287 & 0,524 & 0,539 \\
\hline 22. Vehicles & 1,058 & 1,043 & 1,043 \\
\hline 23. Commerce & 1,050 & 0,897 & 0,853 \\
\hline 24. Transport and Communications & 1,204 & 1,127 & 1,095 \\
\hline 25. Commercial Services & 1,199 & 0,968 & 0,969 \\
\hline 26. Non-commercial services & 1,054 & 0,914 & 0,900 \\
\hline TOTAL & $\mathbf{2 9 , 2 0 9}$ & $\mathbf{2 7 , 1 5 7}$ & $\mathbf{2 6 , 9 5 9}$ \\
\hline Source: Own elaboraton & & & \\
\hline
\end{tabular}

Source: Own elaboration.

$\mathrm{L}$ : Leontief inverse

CGE1: CGE with rigidity in labor market

CGE2: CGE with flexibility in labor market 
Table 3: Total sum of multipliers (net of principal diagonal).

\begin{tabular}{|l|c|c|c|}
\hline Sectors & L & CGE1 & CGE2 \\
\hline 1. Agriculture, cattle and forestry & 0,833 & $-1,755$ & $-3,575$ \\
\hline 2. Fishing & 1,010 & $-1,112$ & $-1,437$ \\
\hline 3. Coal & 1,070 & $-1,061$ & $-0,890$ \\
\hline 4. Oil and Gas & 0,015 & $-0,020$ & $-0,034$ \\
\hline 5. Rest of extractives & 1,113 & $-0,612$ & $-1,028$ \\
\hline 6. Refine & 0,606 & 0,030 & $-0,227$ \\
\hline 7. Electricity & 0,810 & $-1,248$ & $-2,540$ \\
\hline 8. Water & 0,747 & $-0,124$ & $-0,895$ \\
\hline 9. Distribution of water & 1,009 & $-1,266$ & $-1,502$ \\
\hline 10. Food & 1,104 & $-0,908$ & $-1,497$ \\
\hline 11. Manufacturing of textiles and leather & 0,905 & $-0,862$ & $-1,008$ \\
\hline 12. Manufacturing of wood & 0,848 & $-0,909$ & $-1,252$ \\
\hline 13. Chemicals & 0,789 & $-0,625$ & $-0,876$ \\
\hline 14. Mining & 1,130 & $-0,974$ & $-1,315$ \\
\hline 15. Manufacturing of metal products & 0,908 & $-0,613$ & $-0,991$ \\
\hline 16. Machinery & 1,055 & $-0,813$ & $-0,874$ \\
\hline 17. Manufacturing of textiles and leather & 0,657 & $-0,456$ & $-0,505$ \\
\hline 18. Manufacturing of construction material & 0,702 & $-0,387$ & $-0,475$ \\
\hline 19. Transport & 0,773 & $-0,624$ & $-0,441$ \\
\hline 20. Other manufactures & 1,059 & $-0,794$ & $-0,907$ \\
\hline 21. Construction & 1,000 & $-0,607$ & $-0,555$ \\
\hline 22. Vehicles & 0,924 & $-1,321$ & $-1,396$ \\
\hline 23. Commerce & 0,750 & $-1,754$ & $-2,184$ \\
\hline 24. Transport and Communications & 0,647 & $-1,558$ & $-2,303$ \\
\hline 25. Commercial Services & 0,415 & $-1,611$ & $-1,603$ \\
\hline 26. Non-commercial services & 0,517 & $-2,096$ & $-2,259$ \\
\hline TOTAL & $\mathbf{2 1 , 3 9 4}$ & $-24,082$ & $-\mathbf{3 2 , 5 7 0}$ \\
\hline Sourc: Own & & & \\
\hline
\end{tabular}

Source: Own elaboration.

L: Leontief inverse

CGE1: CGE with rigidity in labor market

CGE2: CGE with flexibility in labor market 


\section{CONCLUDING REMARKS}

We have performed some numerical computations using a SAM database of the Spanish economy to estimate multiplier matrices. We first calculate the standard 'unrestricted' Leontief inverse under the usual 'excess supply' assumption whereby resources are available as needed and prices are fixed. We then proceed to estimate two multiplier matrices as numerical approximations of the implicit Jacobian matrix using a CGE model with supply constraints. In the first one, labor and capital are fixed in the aggregate and a policy change in terms of expenditures entails a general reshuffling of resources driven by changes in relative prices. In the second CGE multiplier matrix we contemplate the possibility of using idle labor if needed. In both 'constrained' cases, the multiplier matrices turn out to produce results that are significantly smaller than in the 'unrestricted' Leontief case. A noteworthy result is that a 'crowding out' situation is potentially possible depending upon the characteristics of the labor market. When there is idle labor and employment levels can vary, more government expenditures may not work in the intended plan since the induced general equilibrium reshuffling in prices and activity levels may more than compensate the increased government demand. Results therefore show that the effectiveness of expenditure policies hinges critically on whether or not supply constraints are considered.

\section{REFERENCES}

Barro, R. (2009), Voodoo Multipliers, Economists’ Voice, Berkeley Economic Press, February 2009.

Cardenete, M. A. \& Fuentes, P. (2009). Un Análisis del Sector Energético Español a través de Modelos de Crecimiento Sostenible, Fundación EOI Escuela de Negocios, Madrid, Spain, 2009. 
Devarajan, S., Swaroop, V. \& Zou, H. (1993). What do Government Buy? The Composition of Public Spending and Economic Performance, World Bank Working Paper WPS 1082.

Diamond, J. (1974). The Analysis of Structural Constraints in Developing Economies: a Case Study, Oxford Bulletin of Economics and Statistics, vol. 36, 95-118.

Diamond, J. (1976). Key Sectors in Some Undeveloped Countries: a Comment, Kyklos, vol. 29(4), 762-764.

Guerra, A. I. \& Sancho, F. (2009). Budget-Constrained Government Multipliers. Mimeo, Universitat Autonoma de Barcelona.

Kehoe, T. J, Polo, C. \& Sancho, F. 1995. An evaluation of the performance of an applied general equilibrium model of the Spanish economy. Economic Theory, 6:115141.

Kehoe, T. J., Srinivisan, T.N. \& Whalley, J. (2005). Frontiers in Applied General Equilibrium Modeling. New York: Cambridge University Press.

Leontief, W.W. (1941). The Structure of the American Economy, New York: Oxford University Press.

Nikaido, H. (1972). Introduction to Sets and Mappings in Modern Economics. NorthHolland, Amsterdam, Holland.

Pyatt, G. (1985). Commodity Balances and National Accounts: a Sam Perspective, Review of Income and Wealth, 31(2), 155-169.

Pyatt, G. \& Round, J. (1979). Accounting and Fixprice Multipliers in a Social Accounting Matrix Framework, Economic Journal, 89(356): 850-873. 
Table A1. Leontief Multiplier matrix, using SAM of Spain 2000.

\begin{tabular}{|c|c|c|c|c|c|c|c|c|c|c|c|c|c|}
\hline & 1 & 2 & 3 & 4 & 5 & 6 & 7 & 8 & 9 & 10 & 11 & 12 & 13 \\
\hline 1. Agriculture, cattle and forestry & 1.107 & 0.023 & 0.014 & 0.000 & 0.006 & 0.003 & 0.004 & 0.000 & 0.004 & 0.274 & 0.032 & 0.074 & 0.011 \\
\hline 2. Fishing & 0.001 & 1.002 & 0.002 & 0.000 & 0.001 & 0.000 & 0.000 & 0.000 & 0.000 & 0.005 & 0.002 & 0.001 & 0.001 \\
\hline 3. Coal & 0.002 & 0.001 & 1.005 & 0.000 & 0.005 & 0.002 & 0.113 & 0.000 & 0.003 & 0.002 & 0.002 & 0.003 & 0.002 \\
\hline 4. Oil and Gas & 0.011 & 0.016 & 0.016 & 1.001 & 0.024 & 0.328 & 0.068 & 0.664 & 0.018 & 0.009 & 0.008 & 0.014 & 0.030 \\
\hline 5. Rest of extractives & 0.002 & 0.003 & 0.003 & 0.000 & 1.008 & 0.001 & 0.002 & 0.000 & 0.004 & 0.003 & 0.002 & 0.004 & 0.011 \\
\hline 6. Refine & 0.031 & 0.045 & 0.046 & 0.001 & 0.070 & 1.088 & 0.145 & 0.008 & 0.051 & 0.021 & 0.017 & 0.026 & 0.085 \\
\hline 7. Electricity & 0.016 & 0.013 & 0.049 & 0.001 & 0.038 & 0.012 & 1.173 & 0.004 & 0.031 & 0.018 & 0.017 & 0.032 & 0.017 \\
\hline 8. Water & 0.002 & 0.004 & 0.003 & 0.000 & 0.004 & 0.001 & 0.037 & 1.000 & 0.004 & 0.004 & 0.005 & 0.009 & 0.007 \\
\hline 9. Distribution of water & 0.006 & 0.002 & 0.002 & 0.000 & 0.004 & 0.001 & 0.002 & 0.000 & 1.002 & 0.004 & 0.002 & 0.002 & 0.002 \\
\hline 10. Food & 0.161 & 0.075 & 0.039 & 0.000 & 0.016 & 0.008 & 0.009 & 0.000 & 0.009 & 1.228 & 0.051 & 0.030 & 0.028 \\
\hline 11. Manufacturing of textiles and leather & 0.004 & 0.020 & 0.008 & 0.000 & 0.004 & 0.001 & 0.002 & 0.000 & 0.008 & 0.006 & 1.246 & 0.006 & 0.007 \\
\hline 12. Manufacturing of wood & 0.014 & 0.015 & 0.041 & 0.000 & 0.016 & 0.003 & 0.010 & 0.001 & 0.014 & 0.034 & 0.016 & 1.324 & 0.020 \\
\hline 13. Chemicals & 0.056 & 0.019 & 0.040 & 0.001 & 0.054 & 0.009 & 0.013 & 0.002 & 0.134 & 0.033 & 0.061 & 0.075 & 1.205 \\
\hline 14. Mining & 0.005 & 0.005 & 0.007 & 0.000 & 0.010 & 0.002 & 0.005 & 0.001 & 0.007 & 0.018 & 0.004 & 0.005 & 0.007 \\
\hline 15. Manufacturing of metal products & 0.008 & 0.008 & 0.013 & 0.001 & 0.017 & 0.003 & 0.013 & 0.001 & 0.022 & 0.010 & 0.007 & 0.012 & 0.007 \\
\hline 16. Machinery & 0.018 & 0.015 & 0.017 & 0.002 & 0.032 & 0.006 & 0.031 & 0.002 & 0.029 & 0.024 & 0.011 & 0.024 & 0.009 \\
\hline 17. Manufacturing of textiles and leather & 0.021 & 0.017 & 0.041 & 0.001 & 0.053 & 0.010 & 0.049 & 0.002 & 0.203 & 0.022 & 0.022 & 0.037 & 0.027 \\
\hline 18. Manufacturing of construction material & 0.006 & 0.009 & 0.009 & 0.000 & 0.009 & 0.003 & 0.003 & 0.000 & 0.011 & 0.007 & 0.008 & 0.006 & 0.006 \\
\hline 19. Transport & 0.001 & 0.034 & 0.005 & 0.000 & 0.006 & 0.001 & 0.001 & 0.000 & 0.001 & 0.002 & 0.001 & 0.002 & 0.001 \\
\hline 20. Other manufactures & 0.017 & 0.021 & 0.021 & 0.001 & 0.023 & 0.007 & 0.015 & 0.003 & 0.049 & 0.027 & 0.026 & 0.029 & 0.027 \\
\hline 21. Construction & 0.015 & 0.013 & 0.016 & 0.000 & 0.024 & 0.005 & 0.019 & 0.003 & 0.033 & 0.016 & 0.013 & 0.013 & 0.011 \\
\hline 22. Vehicles & 0.021 & 0.027 & 0.028 & 0.000 & 0.019 & 0.008 & 0.008 & 0.001 & 0.034 & 0.022 & 0.025 & 0.016 & 0.020 \\
\hline 23. Commerce & 0.242 & 0.401 & 0.392 & 0.001 & 0.147 & 0.083 & 0.082 & 0.003 & 0.076 & 0.292 & 0.354 & 0.195 & 0.237 \\
\hline 24. Transport and Communications & 0.066 & 0.081 & 0.109 & 0.002 & 0.387 & 0.048 & 0.049 & 0.009 & 0.058 & 0.085 & 0.066 & 0.101 & 0.071 \\
\hline 25. Commercial Services & 0.073 & 0.098 & 0.101 & 0.002 & 0.102 & 0.044 & 0.094 & 0.033 & 0.167 & 0.119 & 0.112 & 0.100 & 0.110 \\
\hline 26. Non-commercial services & 0.034 & 0.043 & 0.047 & 0.002 & 0.043 & 0.015 & 0.035 & 0.007 & 0.038 & 0.048 & 0.042 & 0.033 & 0.037 \\
\hline TOTAL & 1.939 & 2.012 & 2.075 & 1.016 & 2.121 & 1.694 & 1.983 & 1.747 & 2.011 & 2.332 & 2.151 & 2.172 & 1.994 \\
\hline
\end{tabular}


Table A1 bis. Leontief Multiplier matrix, using SAM of Spain 2000.

\begin{tabular}{|c|c|c|c|c|c|c|c|c|c|c|c|c|c|}
\hline & 14 & 15 & 16 & 17 & 18 & 19 & 20 & 21 & 22 & 23 & 24 & 25 & 26 \\
\hline 1. Agriculture, cattle and forestry & 0.008 & 0.005 & 0.006 & 0.006 & 0.006 & 0.005 & 0.017 & 0.011 & 0.004 & 0.031 & 0.004 & 0.008 & 0.006 \\
\hline 2. Fishing & 0.001 & 0.000 & 0.001 & 0.001 & 0.001 & 0.000 & 0.001 & 0.001 & 0.000 & 0.005 & 0.000 & 0.000 & 0.001 \\
\hline 3. Coal & 0.005 & 0.013 & 0.006 & 0.002 & 0.002 & 0.002 & 0.003 & 0.002 & 0.003 & 0.002 & 0.003 & 0.001 & 0.002 \\
\hline 4. Oil and Gas & 0.025 & 0.016 & 0.011 & 0.005 & 0.005 & 0.007 & 0.010 & 0.010 & 0.008 & 0.009 & 0.032 & 0.005 & 0.007 \\
\hline 5. Rest of extractives & 0.052 & 0.084 & 0.027 & 0.007 & 0.008 & 0.007 & 0.007 & 0.028 & 0.003 & 0.002 & 0.002 & 0.002 & 0.002 \\
\hline 6. Refine & 0.043 & 0.033 & 0.024 & 0.013 & 0.012 & 0.017 & 0.022 & 0.023 & 0.020 & 0.021 & 0.099 & 0.012 & 0.016 \\
\hline 7. Electricity & 0.041 & 0.031 & 0.030 & 0.015 & 0.016 & 0.015 & 0.026 & 0.018 & 0.027 & 0.021 & 0.028 & 0.014 & 0.017 \\
\hline 8. Water & 0.018 & 0.009 & 0.006 & 0.003 & 0.003 & 0.003 & 0.005 & 0.005 & 0.003 & 0.004 & 0.002 & 0.002 & 0.003 \\
\hline 9. Distribution of water & 0.002 & 0.001 & 0.002 & 0.001 & 0.001 & 0.001 & 0.002 & 0.001 & 0.002 & 0.003 & 0.002 & 0.001 & 0.003 \\
\hline 10. Food & 0.021 & 0.011 & 0.014 & 0.017 & 0.015 & 0.011 & 0.023 & 0.013 & 0.008 & 0.101 & 0.008 & 0.007 & 0.013 \\
\hline 11. Manufacturing of textiles and leather & 0.007 & 0.006 & 0.005 & 0.005 & 0.015 & 0.008 & 0.020 & 0.004 & 0.009 & 0.011 & 0.006 & 0.007 & 0.006 \\
\hline 12. Manufacturing of wood & 0.030 & 0.024 & 0.023 & 0.014 & 0.015 & 0.020 & 0.161 & 0.042 & 0.013 & 0.015 & 0.017 & 0.022 & 0.012 \\
\hline 13. Chemicals & 0.062 & 0.078 & 0.062 & 0.028 & 0.030 & 0.039 & 0.103 & 0.041 & 0.040 & 0.024 & 0.019 & 0.024 & 0.027 \\
\hline 14. Mining & 1.093 & 0.008 & 0.010 & 0.009 & 0.010 & 0.008 & 0.007 & 0.166 & 0.012 & 0.008 & 0.009 & 0.005 & 0.011 \\
\hline 15. Manufacturing of metal products & 0.032 & 1.101 & 0.316 & 0.075 & 0.093 & 0.078 & 0.061 & 0.047 & 0.029 & 0.007 & 0.010 & 0.009 & 0.007 \\
\hline 16. Machinery & 0.037 & 0.069 & 1.088 & 0.052 & 0.039 & 0.059 & 0.060 & 0.088 & 0.029 & 0.010 & 0.013 & 0.012 & 0.011 \\
\hline 17. Manufacturing of textiles and leather & 0.074 & 0.054 & 0.063 & 1.141 & 0.053 & 0.098 & 0.041 & 0.095 & 0.036 & 0.022 & 0.053 & 0.025 & 0.031 \\
\hline 18. Manufacturing of construction material & 0.009 & 0.005 & 0.006 & 0.007 & 1.298 & 0.017 & 0.007 & 0.006 & 0.279 & 0.019 & 0.017 & 0.004 & 0.005 \\
\hline 19. Transport & 0.003 & 0.002 & 0.002 & 0.001 & 0.001 & 1.144 & 0.002 & 0.002 & 0.004 & 0.002 & 0.015 & 0.002 & 0.004 \\
\hline 20. Other manufactures & 0.028 & 0.110 & 0.050 & 0.035 & 0.062 & 0.067 & 1.102 & 0.035 & 0.037 & 0.024 & 0.029 & 0.076 & 0.023 \\
\hline 21. Construction & 0.022 & 0.010 & 0.013 & 0.009 & 0.007 & 0.008 & 0.012 & 1.287 & 0.017 & 0.026 & 0.021 & 0.023 & 0.069 \\
\hline 22. Vehicles & 0.020 & 0.011 & 0.012 & 0.013 & 0.017 & 0.010 & 0.017 & 0.015 & 1.058 & 0.066 & 0.022 & 0.005 & 0.008 \\
\hline 23. Commerce & 0.201 & 0.098 & 0.131 & 0.173 & 0.143 & 0.104 & 0.209 & 0.114 & 0.056 & 1.050 & 0.048 & 0.032 & 0.076 \\
\hline 24. Transport and Communications & 0.200 & 0.113 & 0.092 & 0.048 & 0.051 & 0.051 & 0.080 & 0.083 & 0.065 & 0.072 & 1.204 & 0.063 & 0.042 \\
\hline 25. Commercial Services & 0.138 & 0.091 & 0.108 & 0.090 & 0.077 & 0.110 & 0.126 & 0.096 & 0.150 & 0.168 & 0.130 & 1.199 & 0.115 \\
\hline 26. Non-commercial services & 0.053 & 0.028 & 0.034 & 0.026 & 0.022 & 0.027 & 0.037 & 0.056 & 0.069 & 0.078 & 0.059 & 0.054 & 1.054 \\
\hline TOTAL & 2.223 & 2.009 & 2.142 & 1.798 & 2.000 & 1.917 & 2.161 & 2.287 & 1.982 & 1.800 & 1.851 & 1.614 & 1.571 \\
\hline
\end{tabular}

Source: own elaboration. 
Table A2. CGE Multiplier matrix with rigidity in the labor market, using SAM of Spain 2000.

\begin{tabular}{|c|c|c|c|c|c|c|c|c|c|c|c|c|c|}
\hline & 1 & 2 & 3 & 4 & 5 & 6 & 7 & 8 & 9 & 10 & 11 & 12 & 13 \\
\hline 1. Agriculture, cattle and forestry & 1.080 & 0.004 & -0.004 & -0.001 & -0.010 & -0.003 & -0.017 & -0.009 & -0.016 & 0.255 & 0.016 & 0.058 & -0.002 \\
\hline 2. Fishing & 0.001 & 1.001 & 0.001 & 0.000 & 0.000 & 0.000 & 0.000 & 0.000 & 0.000 & 0.004 & 0.001 & 0.000 & 0.001 \\
\hline 3. Coal & -0.001 & -0.001 & 1.002 & 0.000 & 0.003 & 0.001 & 0.111 & -0.001 & 0.001 & 0.000 & 0.000 & 0.001 & 0.001 \\
\hline 4. Oil and Gas & -0.001 & 0.007 & 0.007 & 1.002 & 0.017 & 0.326 & 0.060 & 0.661 & 0.008 & 0.000 & 0.001 & 0.007 & 0.024 \\
\hline 5. Rest of extractives & -0.021 & -0.015 & -0.015 & 0.000 & 0.993 & -0.004 & -0.016 & -0.007 & -0.016 & -0.015 & -0.013 & -0.012 & -0.001 \\
\hline 6. Refine & 0.006 & 0.025 & 0.027 & 0.003 & 0.055 & 1.084 & 0.126 & 0.001 & 0.030 & 0.002 & 0.001 & 0.010 & 0.072 \\
\hline 7. Electricity & -0.008 & -0.006 & 0.030 & -0.001 & 0.022 & 0.006 & 1.154 & -0.005 & 0.011 & 0.000 & 0.001 & 0.016 & 0.004 \\
\hline 8. Water & -0.002 & 0.001 & 0.000 & 0.000 & 0.001 & 0.000 & 0.034 & 0.999 & 0.000 & 0.001 & 0.002 & 0.007 & 0.005 \\
\hline 9. Distribution of water & 0.005 & 0.001 & 0.000 & 0.000 & 0.003 & 0.001 & 0.001 & 0.000 & 1.001 & 0.002 & 0.001 & 0.001 & 0.001 \\
\hline 10. Food & 0.135 & 0.054 & 0.017 & -0.003 & -0.002 & 0.000 & -0.012 & -0.010 & -0.014 & 1.208 & 0.033 & 0.012 & 0.013 \\
\hline 11. Manufacturing of textiles and leather & -0.001 & 0.013 & 0.000 & 0.000 & -0.002 & 0.000 & -0.002 & -0.001 & 0.000 & 0.000 & 1.240 & 0.000 & 0.002 \\
\hline 12. Manufacturing of wood & -0.030 & -0.021 & 0.005 & -0.001 & -0.014 & -0.007 & -0.025 & -0.014 & -0.025 & 0.000 & -0.014 & 1.294 & -0.005 \\
\hline 13. Chemicals & 0.007 & -0.021 & -0.001 & 0.000 & 0.021 & -0.002 & -0.026 & -0.015 & 0.091 & -0.006 & 0.027 & 0.041 & 1.178 \\
\hline 14. Mining & -0.110 & -0.088 & -0.086 & -0.001 & -0.066 & -0.024 & -0.087 & -0.038 & -0.092 & -0.071 & -0.073 & -0.073 & -0.056 \\
\hline 15. Manufacturing of metal products & -0.064 & -0.050 & -0.045 & 0.000 & -0.030 & -0.012 & -0.044 & -0.023 & -0.040 & -0.046 & -0.042 & -0.036 & -0.033 \\
\hline 16. Machinery & -0.094 & -0.076 & -0.073 & 0.001 & -0.042 & -0.019 & -0.058 & -0.036 & -0.068 & -0.063 & -0.064 & -0.052 & -0.052 \\
\hline 17. Manufacturing of textiles and leather & -0.310 & -0.248 & -0.224 & -0.003 & -0.165 & -0.062 & -0.213 & -0.108 & -0.081 & -0.233 & -0.199 & -0.187 & -0.154 \\
\hline 18. Manufacturing of construction material & -0.123 & -0.097 & -0.097 & -0.002 & -0.078 & -0.027 & -0.100 & -0.043 & -0.102 & -0.094 & -0.081 & -0.084 & -0.066 \\
\hline 19. Transport & -0.031 & 0.008 & -0.021 & -0.001 & -0.015 & -0.007 & -0.024 & -0.011 & -0.027 & -0.023 & -0.021 & -0.020 & -0.017 \\
\hline 20. Other manufactures & -0.067 & -0.049 & -0.050 & 0.000 & -0.035 & -0.012 & -0.052 & -0.025 & -0.027 & -0.040 & -0.033 & -0.030 & -0.021 \\
\hline 21. Construction & -0.845 & -0.675 & -0.670 & -0.010 & -0.540 & -0.183 & -0.662 & -0.285 & -0.703 & -0.645 & -0.560 & -0.566 & -0.456 \\
\hline 22. Vehicles & 0.005 & 0.014 & 0.014 & 0.000 & 0.008 & 0.004 & -0.004 & -0.004 & 0.019 & 0.009 & 0.013 & 0.005 & 0.010 \\
\hline 23. Commerce & 0.094 & 0.279 & 0.268 & -0.001 & 0.047 & 0.050 & -0.036 & -0.046 & -0.056 & 0.175 & 0.251 & 0.091 & 0.154 \\
\hline 24. Transport and Communications & -0.022 & 0.010 & 0.038 & 0.002 & 0.329 & 0.030 & -0.021 & -0.020 & -0.018 & 0.018 & 0.007 & 0.041 & 0.023 \\
\hline 25. Commercial Services & -0.189 & -0.119 & -0.118 & -0.001 & -0.075 & -0.014 & -0.115 & -0.054 & -0.065 & -0.087 & -0.069 & -0.082 & -0.036 \\
\hline 26. Non-commercial services & -0.087 & -0.063 & -0.063 & 0.001 & -0.043 & -0.012 & -0.062 & -0.032 & -0.077 & -0.052 & -0.048 & -0.056 & -0.035 \\
\hline TOTAL & -0.675 & -0.111 & -0.059 & 0.982 & 0.381 & 1.114 & -0.094 & 0.874 & -0.266 & 0.299 & 0.378 & 0.384 & 0.553 \\
\hline
\end{tabular}


Table A2 bis. CGE Multiplier matrix with rigidity in the labor market, using SAM of Spain 2000.

\begin{tabular}{|c|c|c|c|c|c|c|c|c|c|c|c|c|c|}
\hline & 14 & 15 & 16 & 17 & 18 & 19 & 20 & 21 & 22 & 23 & 24 & 25 & 26 \\
\hline 1. Agriculture, cattle and forestry & -0.011 & -0.010 & -0.011 & -0.005 & -0.005 & -0.007 & 0.000 & -0.010 & -0.016 & 0.007 & -0.017 & -0.011 & -0.018 \\
\hline 2. Fishing & 0.000 & 0.000 & 0.000 & 0.000 & 0.000 & 0.000 & 0.000 & 0.000 & 0.000 & 0.004 & 0.000 & 0.000 & 0.000 \\
\hline 3. Coal & 0.002 & 0.011 & 0.004 & 0.001 & 0.001 & 0.001 & 0.001 & 0.000 & 0.000 & -0.001 & 0.000 & -0.001 & -0.001 \\
\hline 4. Oil and Gas & 0.016 & 0.009 & 0.003 & 0.000 & 0.001 & 0.001 & 0.002 & 0.000 & -0.002 & -0.003 & 0.022 & -0.004 & -0.005 \\
\hline 5. Rest of extractives & 0.033 & 0.070 & 0.011 & -0.004 & -0.002 & -0.005 & -0.010 & 0.008 & -0.016 & -0.021 & -0.017 & -0.018 & -0.021 \\
\hline 6. Refine & 0.023 & 0.019 & 0.006 & 0.001 & 0.002 & 0.004 & 0.005 & 0.001 & -0.001 & -0.004 & 0.077 & -0.009 & -0.010 \\
\hline 7. Electricity & 0.021 & 0.017 & 0.013 & 0.003 & 0.005 & 0.002 & 0.008 & -0.003 & 0.007 & -0.003 & 0.007 & -0.006 & -0.007 \\
\hline 8. Water & 0.014 & 0.006 & 0.003 & 0.001 & 0.001 & 0.001 & 0.002 & 0.001 & -0.001 & 0.000 & -0.001 & -0.002 & -0.001 \\
\hline 9. Distribution of water & 0.001 & 0.000 & 0.001 & 0.000 & 0.000 & 0.000 & 0.000 & 0.000 & 0.001 & 0.001 & 0.001 & -0.001 & 0.001 \\
\hline 10. Food & -0.001 & -0.006 & -0.006 & 0.003 & 0.002 & -0.004 & 0.003 & -0.011 & -0.015 & 0.075 & -0.015 & -0.015 & -0.013 \\
\hline 11. Manufacturing of textiles and leather & -0.001 & 0.001 & -0.002 & 0.000 & 0.011 & 0.003 & 0.013 & -0.005 & 0.000 & 0.002 & -0.001 & -0.001 & -0.004 \\
\hline 12. Manufacturing of wood & -0.007 & -0.003 & -0.010 & -0.008 & -0.005 & -0.004 & 0.129 & 0.001 & -0.025 & -0.030 & -0.021 & -0.016 & -0.034 \\
\hline 13. Chemicals & 0.020 & 0.048 & 0.025 & 0.004 & 0.008 & 0.012 & 0.067 & -0.004 & -0.003 & -0.026 & -0.024 & -0.018 & -0.026 \\
\hline 14. Mining & 0.997 & -0.061 & -0.075 & -0.046 & -0.040 & -0.054 & -0.077 & 0.063 & -0.087 & -0.108 & -0.091 & -0.093 & -0.109 \\
\hline 15. Manufacturing of metal products & -0.028 & 1.058 & 0.262 & 0.040 & 0.062 & 0.039 & 0.008 & -0.018 & -0.033 & -0.066 & -0.053 & -0.053 & -0.068 \\
\hline 16. Machinery & -0.057 & 0.003 & 1.005 & -0.002 & -0.009 & -0.001 & -0.021 & -0.012 & -0.067 & -0.103 & -0.084 & -0.084 & -0.106 \\
\hline 17. Manufacturing of textiles and leather & -0.201 & -0.142 & -0.180 & 0.983 & -0.090 & -0.078 & -0.198 & -0.201 & -0.247 & -0.311 & -0.234 & -0.256 & -0.313 \\
\hline 18. Manufacturing of construction material & -0.101 & -0.073 & -0.091 & -0.056 & 1.240 & -0.054 & -0.089 & -0.113 & 0.167 & -0.113 & -0.097 & -0.109 & -0.133 \\
\hline 19. Transport & -0.024 & -0.017 & -0.022 & -0.015 & -0.013 & 1.126 & -0.022 & -0.027 & -0.023 & -0.031 & -0.013 & -0.026 & -0.030 \\
\hline 20. Other manufactures & -0.045 & 0.059 & -0.015 & -0.007 & 0.024 & 0.020 & 1.038 & -0.044 & -0.038 & -0.063 & -0.045 & 0.002 & -0.068 \\
\hline 21. Construction & -0.690 & -0.497 & -0.616 & -0.400 & -0.363 & -0.446 & -0.607 & 0.524 & -0.712 & -0.835 & -0.721 & -0.705 & -0.820 \\
\hline 22. Vehicles & 0.006 & 0.001 & -0.001 & 0.005 & 0.009 & 0.001 & 0.005 & -0.001 & 1.043 & 0.049 & 0.008 & -0.010 & -0.010 \\
\hline 23. Commerce & 0.074 & 0.008 & 0.018 & 0.100 & 0.077 & 0.021 & 0.098 & -0.024 & -0.075 & 0.897 & -0.083 & -0.100 & -0.084 \\
\hline 24. Transport and Communications & 0.126 & 0.061 & 0.027 & 0.006 & 0.013 & 0.004 & 0.016 & 0.004 & -0.010 & -0.017 & 1.127 & -0.012 & -0.050 \\
\hline 25. Commercial Services & -0.086 & -0.068 & -0.092 & -0.040 & -0.040 & -0.035 & -0.069 & -0.147 & -0.081 & -0.103 & -0.101 & 0.968 & -0.166 \\
\hline 26. Non-commercial services & -0.057 & -0.049 & -0.065 & -0.038 & -0.036 & -0.046 & -0.060 & -0.065 & -0.046 & -0.054 & -0.052 & -0.062 & 0.914 \\
\hline TOTAL & 0.023 & 0.446 & 0.192 & 0.527 & 0.853 & 0.502 & 0.244 & -0.084 & -0.278 & -0.857 & -0.431 & -0.643 & -1.181 \\
\hline
\end{tabular}

Source: own elaboration. 
Table A3. CGE Multiplier matrix with flexible labor market, using SAM of Spain 2000.

\begin{tabular}{|c|c|c|c|c|c|c|c|c|c|c|c|c|c|}
\hline & 1 & 2 & 3 & 4 & 5 & 6 & 7 & 8 & 9 & 10 & 11 & 12 & 13 \\
\hline 1. Agriculture, cattle and forestry & 1.051 & -0.001 & -0.001 & -0.001 & -0.017 & -0.007 & -0.038 & -0.022 & -0.019 & 0.246 & 0.014 & 0.053 & -0.006 \\
\hline 2. Fishing & -0.003 & 1.001 & 0.001 & 0.000 & -0.001 & 0.000 & -0.003 & -0.002 & -0.001 & 0.003 & 0.001 & 0.000 & 0.000 \\
\hline 3. Coal & -0.004 & -0.001 & 1.003 & 0.000 & 0.003 & 0.001 & 0.109 & -0.002 & 0.000 & -0.001 & -0.001 & 0.001 & 0.000 \\
\hline 4. Oil and Gas & -0.013 & 0.005 & 0.008 & 1.002 & 0.014 & 0.325 & 0.051 & 0.656 & 0.007 & -0.004 & 0.000 & 0.004 & 0.023 \\
\hline 5. Rest of extractives & -0.033 & -0.017 & -0.014 & 0.000 & 0.990 & -0.006 & -0.024 & -0.012 & -0.017 & -0.019 & -0.014 & -0.014 & -0.003 \\
\hline 6. Refine & -0.025 & 0.020 & 0.029 & 0.002 & 0.048 & 1.079 & 0.104 & -0.012 & 0.026 & -0.008 & -0.002 & 0.004 & 0.067 \\
\hline 7. Electricity & -0.027 & -0.009 & 0.032 & -0.001 & 0.018 & 0.003 & 1.141 & -0.013 & 0.009 & -0.006 & -0.001 & 0.013 & 0.001 \\
\hline 8. Water & -0.006 & 0.000 & 0.000 & 0.000 & 0.000 & 0.000 & 0.031 & 0.997 & 0.000 & -0.001 & 0.002 & 0.006 & 0.004 \\
\hline 9. Distribution of water & 0.002 & 0.000 & 0.001 & 0.000 & 0.002 & 0.000 & -0.001 & -0.002 & 1.000 & 0.002 & 0.001 & 0.000 & 0.001 \\
\hline 10. Food & 0.068 & 0.042 & 0.024 & -0.004 & -0.018 & -0.009 & -0.060 & -0.038 & -0.022 & 1.186 & 0.028 & -0.001 & 0.003 \\
\hline 11. Manufacturing of textiles and leather & -0.035 & 0.007 & 0.003 & 0.000 & -0.009 & -0.005 & -0.026 & -0.015 & -0.004 & -0.011 & 1.238 & -0.006 & -0.002 \\
\hline 12. Manufacturing of wood & -0.061 & -0.027 & 0.007 & -0.001 & -0.021 & -0.011 & -0.047 & -0.027 & -0.029 & -0.011 & -0.017 & 1.288 & -0.009 \\
\hline 13. Chemicals & -0.035 & -0.028 & 0.003 & 0.000 & 0.011 & -0.008 & -0.056 & -0.032 & 0.086 & -0.020 & 0.024 & 0.033 & 1.172 \\
\hline 14. Mining & -0.170 & -0.099 & -0.080 & -0.002 & -0.080 & -0.032 & -0.129 & -0.063 & -0.100 & -0.091 & -0.078 & -0.085 & -0.065 \\
\hline 15. Manufacturing of metal products & -0.105 & -0.057 & -0.042 & 0.000 & -0.040 & -0.018 & -0.073 & -0.040 & -0.046 & -0.059 & -0.045 & -0.044 & -0.038 \\
\hline 16. Machinery & -0.156 & -0.087 & -0.068 & 0.000 & -0.056 & -0.027 & -0.102 & -0.061 & -0.076 & -0.083 & -0.069 & -0.064 & -0.061 \\
\hline 17. Manufacturing of textiles and leather & -0.489 & -0.280 & -0.208 & -0.004 & -0.206 & -0.088 & -0.340 & -0.183 & -0.104 & -0.293 & -0.214 & -0.221 & -0.179 \\
\hline 18. Manufacturing of construction material & -0.210 & -0.112 & -0.089 & -0.003 & -0.097 & -0.039 & -0.161 & -0.080 & -0.113 & -0.123 & -0.088 & -0.100 & -0.078 \\
\hline 19. Transport & -0.048 & 0.005 & -0.019 & -0.001 & -0.019 & -0.009 & -0.037 & -0.018 & -0.029 & -0.029 & -0.022 & -0.024 & -0.019 \\
\hline 20. Other manufactures & -0.136 & -0.061 & -0.044 & -0.001 & -0.050 & -0.022 & -0.100 & -0.053 & -0.035 & -0.062 & -0.038 & -0.043 & -0.030 \\
\hline 21. Construction & -1.269 & -0.749 & -0.630 & -0.014 & -0.636 & -0.244 & -0.962 & -0.462 & -0.757 & -0.785 & -0.594 & -0.646 & -0.515 \\
\hline 22. Vehicles & -0.017 & 0.010 & 0.016 & 0.000 & 0.003 & 0.001 & -0.020 & -0.013 & 0.016 & 0.001 & 0.011 & 0.000 & 0.007 \\
\hline 23. Commerce & -0.076 & 0.249 & 0.284 & -0.002 & 0.009 & 0.026 & -0.156 & -0.117 & -0.078 & 0.119 & 0.237 & 0.059 & 0.130 \\
\hline 24. Transport and Communications & -0.100 & -0.003 & 0.045 & 0.002 & 0.311 & 0.019 & -0.076 & -0.053 & -0.027 & -0.008 & 0.001 & 0.027 & 0.012 \\
\hline 25. Commercial Services & -0.388 & -0.154 & -0.100 & -0.003 & -0.120 & -0.042 & -0.255 & -0.137 & -0.090 & -0.153 & -0.084 & -0.119 & -0.064 \\
\hline 26. Non-commercial services & -0.239 & -0.090 & -0.049 & -0.001 & -0.077 & -0.034 & -0.169 & -0.095 & -0.097 & -0.102 & -0.060 & -0.085 & -0.056 \\
\hline TOTAL & -2.524 & -0.437 & 0.113 & 0.967 & -0.038 & 0.852 & -1.400 & 0.102 & -0.502 & -0.312 & 0.230 & 0.035 & 0.296 \\
\hline
\end{tabular}


Table A3 bis. CGE Multiplier matrix with flexible labor market, using SAM of Spain 2000.

\begin{tabular}{|c|c|c|c|c|c|c|c|c|c|c|c|c|c|}
\hline & 14 & 15 & 16 & 17 & 18 & 19 & 20 & 21 & 22 & 23 & 24 & 25 & 26 \\
\hline 1. Agriculture, cattle and forestry & -0.017 & -0.016 & -0.012 & -0.006 & -0.006 & -0.004 & -0.001 & -0.009 & -0.017 & 0.000 & -0.030 & -0.011 & -0.021 \\
\hline 2. Fishing & 0.000 & -0.001 & 0.000 & 0.000 & 0.000 & 0.000 & 0.000 & 0.000 & 0.000 & 0.003 & -0.002 & 0.000 & -0.001 \\
\hline 3. Coal & 0.002 & 0.010 & 0.003 & 0.001 & 0.001 & 0.001 & 0.001 & 0.000 & 0.000 & -0.001 & -0.001 & -0.001 & -0.001 \\
\hline 4. Oil and Gas & 0.013 & 0.007 & 0.003 & 0.000 & 0.000 & 0.003 & 0.001 & 0.001 & -0.002 & -0.006 & 0.017 & -0.004 & -0.006 \\
\hline 5. Rest of extractives & 0.031 & 0.068 & 0.010 & -0.004 & -0.002 & -0.004 & -0.010 & 0.008 & -0.016 & -0.024 & -0.022 & -0.017 & -0.022 \\
\hline 6. Refine & 0.017 & 0.013 & 0.005 & 0.001 & 0.000 & 0.007 & 0.003 & 0.002 & -0.002 & -0.012 & 0.064 & -0.008 & -0.013 \\
\hline 7. Electricity & 0.017 & 0.013 & 0.012 & 0.003 & 0.004 & 0.004 & 0.007 & -0.002 & 0.006 & -0.007 & -0.001 & -0.006 & -0.009 \\
\hline 8. Water & 0.014 & 0.005 & 0.003 & 0.000 & 0.001 & 0.001 & 0.002 & 0.001 & -0.001 & -0.001 & -0.003 & -0.002 & -0.002 \\
\hline 9. Distributio & 0.000 & 0.000 & 0.001 & 0.000 & 0.000 & 0.001 & 0.000 & 0.000 & 0.000 & 0.000 & -0.001 & 0.000 & 0.000 \\
\hline 10. Food & -0.014 & -0.020 & -0.008 & 0.001 & -0.002 & 0.002 & -0.001 & -0.008 & -0.017 & 0.058 & -0.043 & -0.015 & -0.020 \\
\hline 11. Manufacturing of textiles & -0.007 & -0.006 & -0.003 & -0.001 & 0.009 & 0.006 & 0.011 & -0.004 & -0.001 & -0.007 & -0.015 & -0.001 & -0.008 \\
\hline 12. Manufacturing of wood & -0.013 & -0.009 & -0.011 & -0.008 & -0.006 & -0.001 & 0.127 & 0.003 & -0.027 & -0.038 & -0.034 & -0.016 & -0.037 \\
\hline 13. Chemicals & 0.012 & 0.039 & 0.024 & 0.003 & 0.006 & 0.017 & 0.064 & -0.003 & -0.004 & -0.037 & -0.042 & -0.018 & -0.030 \\
\hline 14. Mining & 0.986 & -0.073 & -0.077 & -0.048 & -0.043 & -0.048 & -0.081 & 0.065 & -0.089 & -0.123 & -0.116 & -0.093 & -0.115 \\
\hline 15. Manufacturing of $\mathrm{m}$ & -0.036 & 1.050 & 0.261 & 0.039 & 0.060 & 0.043 & 0.006 & -0.016 & -0.035 & -0.076 & -0.070 & -0.053 & -0.072 \\
\hline 16. Machinery & -0.069 & -0.010 & 1.003 & -0.004 & -0.012 & 0.005 & -0.025 & -0.010 & -0.070 & -0.119 & -0.110 & -0.084 & -0.112 \\
\hline 17. Manuf & -0.235 & -0.180 & -0.186 & 0.977 & -0.099 & -0.060 & -0.209 & -0.194 & -0.254 & -0.357 & -0.309 & -0.256 & -0.330 \\
\hline 18. Manufacturing of construction material & -0.117 & -0.091 & -0.094 & -0.059 & 1.236 & -0.045 & -0.094 & -0.110 & 0.163 & -0.136 & -0.133 & -0.109 & -0.141 \\
\hline 19. Transport & -0.027 & -0.021 & -0.023 & -0.015 & -0.014 & 1.128 & -0.023 & -0.027 & -0.024 & -0.035 & -0.021 & -0.026 & -0.031 \\
\hline 20. Other manufactures & -0.058 & 0.045 & -0.017 & -0.009 & 0.021 & 0.026 & 1.034 & -0.041 & -0.040 & -0.081 & -0.074 & 0.002 & -0.074 \\
\hline 21. Construction & -0.771 & -0.586 & -0.631 & -0.413 & -0.384 & -0.404 & -0.633 & 0.539 & -0.729 & -0.944 & -0.900 & -0.703 & -0.861 \\
\hline 22. Vehicles & 0.001 & -0.004 & -0.001 & 0.004 & 0.008 & 0.003 & 0.003 & 0.000 & 1.043 & 0.044 & -0.002 & -0.010 & -0.012 \\
\hline 23. Commerce & 0.041 & -0.027 & 0.012 & 0.095 & 0.069 & 0.038 & 0.087 & -0.018 & -0.082 & 0.853 & -0.155 & -0.099 & -0.101 \\
\hline 24. Transport and Com & 0.111 & 0.044 & 0.025 & 0.004 & 0.010 & 0.012 & 0.011 & 0.007 & -0.014 & -0.037 & 1.095 & -0.011 & -0.057 \\
\hline 25. Commercial Services & -0.124 & -0.110 & -0.098 & -0.046 & -0.050 & -0.015 & -0.082 & -0.139 & -0.089 & -0.154 & -0.185 & 0.969 & -0.185 \\
\hline 26. Non-commercial services & -0.086 & -0.081 & -0.070 & -0.043 & -0.044 & -0.031 & -0.070 & -0.060 & -0.052 & -0.093 & -0.116 & -0.061 & 0.900 \\
\hline TOTAL & -0.329 & 0.059 & 0.129 & 0.472 & 0.760 & 0.687 & 0.127 & -0.016 & -0.353 & -1.331 & -1.209 & -0.634 & -1.359 \\
\hline
\end{tabular}

Source: own elaboration. 